\title{
EFFECT OF ROTATIONAL SPEED OF A SELF-ASPIRATING MIXER ON OXYGEN SATURATION IN WATER
}

\author{
Andrzej Wróblewski \\ Aldona Skotnicka-Siepsiak \\ University of Warmia and Mazury in Olsztyn, Poland
}

\begin{abstract}
There are two categories of gas-liquid mixers: conventional and special-purpose. In theory, any conventional mixer can be applied to aerate a liquid, but fast-rotating devices are generally preferred. Special-purpose mixers (tubular, prismatic, cylindrical) have a hollow shaft, and operate by drawing gas from above the surface of the liquid and dispersing it inside the liquid. This process is referred to as aspirated aeration. In contrast, conventional mixers increase the pressure of the aspirated gas. Gas drawn from above the surface of the liquid flows through channels bored inside the shaft and the impeller, and is introduced to the liquid in this way. This article presents the results of an experiment investigating the aeration efficiency of a six-tube self-aspirating mixer at different rotational speeds. The experiment was conducted in a flow tank. The results indicate that self-aspirating mixers are effective devices for water aeration and mixing.
\end{abstract}

Keywords: water aeration,self-aspirating mixer,tubular mixer

\section{INTRODUCTION}

The oxygen content of water is a very important consideration in analyses of environmental processes, and this problem has been addressed by numerous researchers. According to Gamo [1], the concentration of oxygen at the bottom of the Sea of Japan has decreased by approximately $8-10 \%$ over the last 30 years, which can be attributed to global climate change and higher sea surface temperatures in winter. Seasonal changes in oxygen concentration in the North Sea have also been extensively researched [2]. An analysis of more than 19,000 sets of data covering the period 1980 to 2010 revealed that oxygen concentration ranged between 0.9 and $1.8 \mathrm{mg} / \mathrm{l}$ between July and October. Human activities also induce changes in the surface aeration of bodies of water and rivers. Stigebrandt and Kalen [3] evaluated the effect of hypolimnetic oxygenation in five Danish lakes, and demonstrated that deep water aeration should be used only as a temporary strategy to promote the survival of aquatic organisms in anaerobic periods. To promote a sustainable increase in oxygen concentration, this method should be combined with a reduction in nutrient levels. Mostefa and Ahmed [4] analysed the effectiveness of hypolimnetic oxygenation with the use of the "Tanytarsus" diffuser system in Lake Hallwil in Switzerland. In a study by Stigebrandt et al. [5], the deep water of the anoxic By Fjord in Sweden was aerated with oxygen aspirated from the surface. A 10-year study of forced aeration and destratification was also carried out in Lake Długie in Olsztyn [5]. Aeration techniques have 
been successfully used to remediate the Oeiras River in Portugal, the Emsche in Germany, the Thames in the UK, and the Homewood Canal in the USA [7].

Aeration is widely applied in the treatment of water and effluent to enhance the biological potential of wastewater and make it suitable for reuse. Water is aerated via the use of pressure aerators, air-stripping towers, bubble diffusers, surface aerators and cascade aerators with aeration nozzles [8], and new technologies for water and wastewater treatment are being constantly developed [9]. Advanced oxidation processes (AOPs) show considerable potential in view of the provisions of Directive 2013/39/EU on priority substances in the field of water policy [10], since these treatments can remove natural organic matter [11] and pharmaceuticals [12] from drinking water. AOPs are also applied in hybrid treatment processes, sulphate-radical oxidation, heterogeneous semiconductor photocatalysis and electrochemical advanced oxidation for water/wastewater treatment [13]. AOPs can also be combined with biological methods to reduce costs [14]. Recent years have also witnessed considerable interest in electrochemical oxidation, which is particularly effective in removing textile, olive oil, pulp, paper mill and tannery effluents [15]. Kumar, Nidheesh and Kumar [16] relied on the above method to remove colour and chemical oxygen demand (COD). Efforts are also being made to optimise and improve existing technologies. Aeration processes can be modelled to minimise the demand for energy during effluent and water treatment without compromising the quality of the water. Aeration is the most energy-intensive process in wastewater treatments that rely on the activated sludge method. During upgrading of a wastewater treatment plant in Tychy, energy consumption was decreased to $0.46 \mathrm{kWh} / \mathrm{m}^{3}$ by modelling the demand for oxygen in the activated sludge process and introducing efficient aeration devices [17]. Asadi et al. [18] analysed industrial data obtained from the Detroit Water and Sewerage Department, which provides water and wastewater services to around 35\% of Michigan's population. They relied on a multi-adaptive regression spline algorithm to demonstrate that the airflow rate could be decreased by around $31 \%$ while keeping the quality of the water within the acceptable range. Numerical simulation methods were also employed by Daskiran et al. [19], who developed a large eddy simulation model for a modular pump-turbine to analyse oxygen dissolution inside the draft tube. Kalenik et al. [20] analysed the effects of air and water flow rates on the oxygen content of water oxygenated in a pipe aerator. Filtering and aeration technologies are also being optimised, such as the use of biological aerated filters for the removal of iron and manganese ions in water treatment [21]. Future research is likely to focus on up-flow biological aeration filters (BAFs) and non-pathogenic microbes isolated from the resident environment. Bao et al. [22] investigated the applicability of autoclaved aerate concrete particles in BAFs. Kujawiak et al. [23] analysed the effectiveness of aeration in moving bed airlift bioreactors, and found that beds with a high specific surface area improved aeration and that the optimal position of the aeration nozzle in the airlift pump significantly improved circulation and increased oxygen concentration in the reactor. Boog et al. [24] examined the application of two prototype systems, a saturated horizontal flow system (HA) and a saturated vertical down-flow system (VA), for aerated sub-surface flow treatment wetlands, to determine the resilience of organic carbon and nitrogen removal processes after an interruption in aeration. Freeman et al. [25] proposed a new aeration approach for sites such as airports, which was based on unplanted, artificially aerated, horizontal subsurface flow constructed wetlands. The described solution was significantly more effective in removing pollutants than alternative methods, and more than $90 \%$ of the influent load for COD, BOD 5 and TOC was removed. Shulka and Goel [26] analysed the performance of two sets of solid jet aerators with openings with areas of $594.96 \mathrm{~mm}^{2}$ and $246.30 \mathrm{~mm}^{2}$ and rectangular nozzles with rounded ends. In an article by Shukla et al. [27], the authors analysed the impact of changes to the shapes of the aerator holes on the efficiency of the oxygenation process. Of the different types of jet geometry considered (elliptical, circular, rectangular, and rectangular with rounded edge) they reported that the most beneficial shape for high oxygen transfer aerators was rectangular openings with rounded ends. Ghotli et al. [28] dealt with the influence of rotor design, mixing time and air entrainment point, and carried out a study of a single liquid phase under turbulent conditions using both conventional and new impeller designs. Experimental comparative studies of various aerator designs were presented in [29], involving various configurations of the aeration process and energy consumption, and curved blade impellers with three, six, nine, and 12 blades. The optimal configuration turned out to be a construction with nine blades. Work by Du et al. [30] focused on sewage collection and aeration in rectangular water tanks, which were compared with three layouts of fine-pore aeration tubes (a disc-type diffuser, a four-cornertype diffuser and a distribute-type diffuser) at three airflow rates. The issue of maintaining the critical level of oxygen concentration in fluids with high viscosity was studied in [31], and the authors examined how the aeration efficiency could be enhanced by operating a downward-pumping highsolidity ratio central impeller at a low critical speed with a slowly-rotating anchor impeller.

Special attention was paid to published studies aiming to optimise or develop new structural solutions for aeration mixers. Rzymski and Stelmach [32] analysed aeration processes involving a helical screw and ribbon impellers. Stelmach [33] investigated the effectiveness of turbine-disc impellers with a stator, and Heim and Stelmach [34] examined several types of impellers for sparger aeration. Various solutions for modifying impellers with diagonally folded blades were also analysed [35]. It appears that a self-aspirating mixer with a tubular structure could pose an alternative solution; this device has a simple structure and does not require an external air supply source, which minimises operating costs without compromising aeration efficiency. A self-aspirating mixer with a tubular structure was designed, built and tested in this study (Fig. 1). 


\section{MEASUREMENT METHODS}

The air flow rate can be measured in water treatment plants and in wastewater treatment plants with the activated sludge system using models to simulate the activated sludge treatment process. In a water treatment plant, the aeration rate is determined by removing oxygen from the water and measuring the increase in the oxygen content of the water over time. The concept of oxygenation capacity was developed by Kessener and Ribbius, and was further elaborated by Pasveer [36], who proposed the following formula:

$$
O C=11.33 \cdot \frac{1}{\Delta t} \ln \frac{D_{0}}{D_{t}} \cdot \sqrt{\frac{k_{10}}{k_{t}}}
$$

where OC is the oxygenation capacity in $\mathrm{g} / \mathrm{m}^{3} \mathrm{~h}$,

the value 11.33 is the oxygen saturation in water at a temperature of $10^{\circ} \mathrm{C}$, where water comes into contact with air with $20.9 \%$ oxygen content under an atmospheric pressure of $1013 \mathrm{hPa}$, in $\mathrm{g} / \mathrm{m}^{3}$,

$\Delta \mathrm{t}=\mathrm{t}_{1}-\mathrm{t}_{0}$ is the observation time, in $\mathrm{h}$,

$\mathrm{D}_{0}=\mathrm{C}_{\mathrm{S}}-\mathrm{C}_{0}$, in $\mathrm{g} / \mathrm{m}^{3}$,

$\mathrm{D}_{\mathrm{t}}=\mathrm{C}_{\mathrm{S}}-\mathrm{C}_{\mathrm{t}}$, in $\mathrm{g} / \mathrm{m}^{3}$,

$\mathrm{C}_{0}$ is the initial oxygen concentration, in $\mathrm{g} / \mathrm{m}^{3}$,

$\mathrm{C}_{\mathrm{S}}$ is the oxygen saturation, in $\mathrm{g} / \mathrm{m}^{3}$,

$\mathrm{C}_{\mathrm{t}}$ is the oxygen concentration after time $\mathrm{t}$, in $\mathrm{g} / \mathrm{m}^{3}$,

$\sqrt{\frac{k_{10}}{k}}$ is the coefficient for temperature compensation, where $\mathrm{k}_{\mathrm{t}}$ is the temperature of the experimental water, and $\mathrm{k}_{10}$ is the reference temperature $\left(10^{\circ} \mathrm{C}\right)$ (Table 1$)$.

Table 1. Ratio of oxygen diffusion constants $\sqrt{\frac{k_{10}}{k_{t}}}$ for different temperatures $\left({ }^{\circ} \mathrm{C}\right)$.

\begin{tabular}{|c|c|c|c|}
\hline Temperature ${ }^{\circ} \mathrm{C}$ & $\sqrt{\frac{k_{10}}{k_{t}}}$ & Temperature ${ }^{\circ} \mathrm{C}$ & $\sqrt{\frac{k_{10}}{k_{t}}}$ \\
\hline 9 & 1.019 & 17 & 0.878 \\
10 & 1.000 & 18 & 0.861 \\
11 & 0.982 & 19 & 0.845 \\
12 & 0.964 & 20 & 0.830 \\
13 & 0.946 & 21 & 0.815 \\
14 & 0.928 & 22 & 0.799 \\
15 & 0.911 & 23 & 0.784 \\
16 & 0.895 & 24 & 0.770 \\
\hline
\end{tabular}

Oxygenation capacity (OC) describes the rate at which oxygen is introduced to deoxygenated water $\left(0 \mathrm{mg} \mathrm{O}_{2} / \mathrm{m}^{3}\right)$ at a temperature of $10^{\circ} \mathrm{C}$ under an atmospheric pressure of $1013 \mathrm{hPa}$. A formula describing the effect of temperature on $\mathrm{OC}$ values can be used to perform measurements under different conditions:

$$
O C_{(t)}=O C_{10} \cdot \frac{C_{S(t)}}{C_{S(10)}} \cdot \sqrt{\frac{k_{t}}{k_{10}}}
$$

OC can also be expressed in terms of the overall coefficient of oxygen transfer $\mathrm{K}_{\mathrm{La}}$. The relationship between $\mathrm{OC}$ and $\mathrm{K}_{\mathrm{La}}$ can be described as follows:

$$
O C=C_{s} K_{L a}
$$

where $\mathrm{C}_{\mathrm{s}}$ is the oxygen saturation at a temperature of $10^{\circ} \mathrm{C}$ under an atmospheric pressure of $1013 \mathrm{hPa}$, in $\mathrm{g} / \mathrm{m}^{3}$.

Since $\mathrm{K}_{\mathrm{La}}$ is determined at a temperature of $20^{\circ} \mathrm{C}$, the relevant adjustments have to be made to the calculations of $\mathrm{K}$ and $\mathrm{OC}$.

In real-life conditions, the value of $\mathrm{K}_{\mathrm{La}}$ is generally lower for sewage than for mains water. A coefficient $a$ was therefore introduced to express the correlation between the OC of sewage and the OC of mains water.

$$
\alpha=\frac{K_{L a}(\text { sewage })}{K_{L a}(\text { water })}
$$

Since $\alpha$ is calculated for a specific sewage sample, and oxygen saturation in wastewater generally differs from that determined in mains water, a further coefficient $\beta$ was introduced:

$$
\beta=\frac{C_{S}^{\prime}(\text { sewage })}{C_{S}(\text { water })}
$$

For an atmospheric pressure other than $1013 \mathrm{hPa}$, the oxygen saturation in water is calculated using the following equation:

$$
\left(C_{S}\right)_{p}=\left(C_{S}\right)_{1013}\left[\frac{P-p}{1013-p}\right]
$$

where $\mathrm{P}$ is the pressure under aeration conditions, in $\mathrm{hPa}$, and $\mathrm{p}$ is the saturation pressure of water vapour, in $\mathrm{hPa}$.

The influence of temperature on the value of the coefficient $\mathrm{K}_{\mathrm{La}}$ is expressed by the following formula:

$$
\left(K_{L a}\right)_{t}=\left(K_{L a}\right)_{20} \cdot 1.024^{(t-20)}
$$

where $\mathrm{t}$ is the temperature under specific aeration conditions.

The total OC under the given conditions can be expressed by the following formula [31]:

$$
O C=\alpha\left(K_{L a}\right)_{20}\left[\frac{P-p}{1013-p} \beta C_{S}-C_{L}\right] \cdot 1.024^{(t-20)}
$$

where $\mathrm{C}_{L}$ is the oxygen concentration in the aeration chamber in the activated sludge process, in $\mathrm{g} / \mathrm{m}^{3}$. 


\section{EXPERIMENTAL DESIGN}

The experiment involved a self-aspirating mixer composed of six tubes. A design patent application for the mixer has been submitted to the patent office (Fig. 1). The self-aspirating mixer operates on a very simple principle: the tubes (Fig. 1) (2) are bevelled at an angle, and negative pressure is produced at the end of the impeller tubes at a given rotational speed in a given direction (Fig. 1) (2). As a result of the difference in pressure, air above the surface of the water is drawn in and diffused into the liquid.

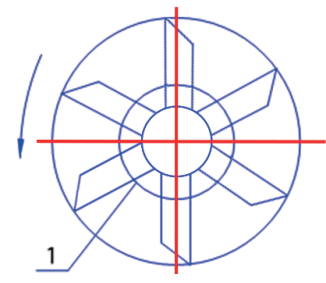

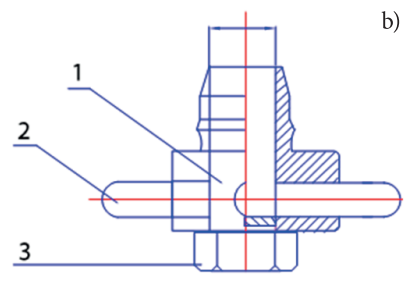

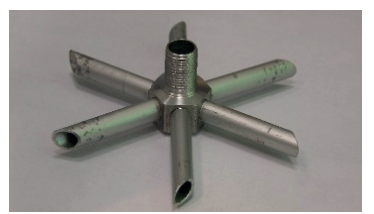

Fig. 1. Six-tube mixer: (a) top view of the mixer; (b) cross-sectional view of the mixer (1 - body, 2 - tube, 3 -screw); (c) photograph of the mixer.

The experiment was conducted in a flow tank measuring $1.2 \times 0.8 \times 0.4 \mathrm{~m}$. Oxygen content was measured with two oxygen probes, one of which was placed inside aeration chamber 1, and the other in aeration chamber 2 (Fig. 2). The data supplied by the probes were analysed to determine the dissolution of oxygen from the air supplied by the aerator.

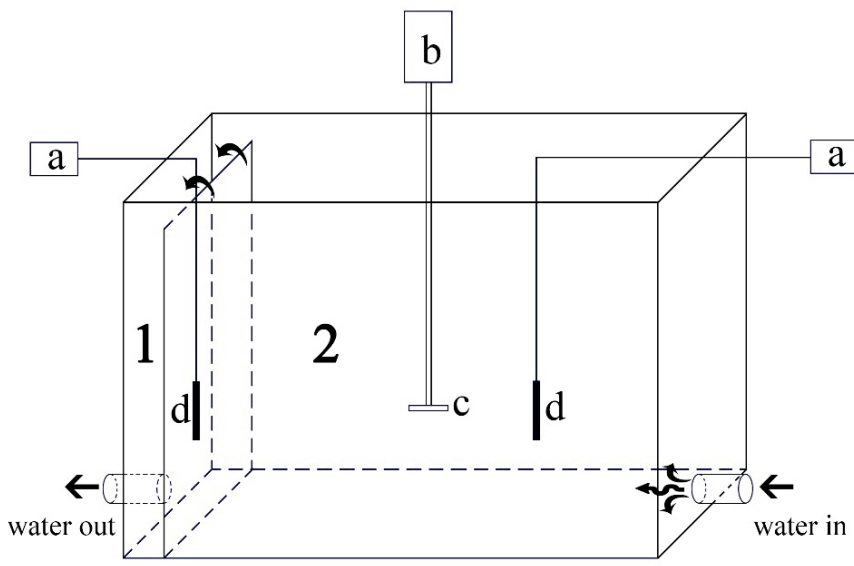

Figure 2. Diagram of the test stand: 1-chamber1, 2-chamber2:( a) oxygen meter, (b) engine, (c) six-tube mixer, (d) oxygen sensor

Measurements were performed using Elmetron laboratory oxygen sensors with a detection range of 0 to $60 \mathrm{mg} / \mathrm{dm}^{3}$ and a resolution of $0.001 \mathrm{mg} / \mathrm{dm}^{3}$. These sensors automatically compensate for the effects of atmospheric pressure and temperature on the oxygen concentration of a liquid. The dose of $\mathrm{Na}_{2} \mathrm{HSO}_{3}$ required for oxygen removal was determined based on the results of previous experiments. $\mathrm{Na}_{2} \mathrm{HSO}_{3}$ solution was added to water in a separate $1.2 \mathrm{~m}^{3}$ tank and stirred for $3 \mathrm{~min}$. The oxygen concentration of the water was checked every $3 \mathrm{~min}$, and when this had stabilised, it was adopted as the initial value $\left(C_{p}\right)$. The rate at which oxygen was dissolved in the water was determined using a self-designed mixer composed of six tubes with a diameter of $50 \mathrm{~mm}$ (Fig. 1), at various rotational speeds in the range $n=1000$ to $4000 \mathrm{rpm}$ and a flow rate of $\mathrm{Q}=70 \mathrm{dm}^{3} / \mathrm{min}$. The oxygen concentration of the water was measured every $5 \mathrm{~s}$. The data were used to calculate the OC using Equation (1), and the results are shown in Figures 4 and 6. The period of measurement at a rotational speed of $4000 \mathrm{rpm}$ was shortened for safety reasons.

\section{RESULTS}

The results of the experiment indicate that the OC increased considerably in the first stage of aeration with the self-aspirating mixer. The first stage of aeration generally lasted 100 to $400 \mathrm{~s}$, subject to rotational speed, and the OC decreased successively after that time.

Oxygen concentration $C_{x}$ increased with a rise in OC, within the first 50-400 s of aeration on average, and then stabilised. Oxygen levels increased proportionally with an increase in rotational speed, i.e. the higher the speed, the higher the value of $\mathrm{C}_{\mathrm{x}}$. When the changes in the values of $\mathrm{C}_{x}$ (Fig. 3) and OC (Fig. 4) in chamber 2 are compared with the changes in the values of $\mathrm{C}_{\mathrm{x}}$ (Fig. 5) and OC (Fig. 6) in chamber 1 , certain variations can be observed in the maximum values obtained in both chambers. The values of $\mathrm{C}_{\mathrm{x}}$ and $\mathrm{OC}$ were higher in chamber 1 than in chamber 2 . The values of $\mathrm{OC}$ were higher by $3 \mathrm{~kg} \mathrm{O} / \mathrm{m}^{3} \mathrm{~h}$ in chamber 1 (Fig. 6) than in chamber 2 (Fig. 4). In chamber 2, water was intensively aerated, while deaerated water was mixed. The aerated and mixed water then flowed into chamber 1 , which can explain the differences in OC values (Fig. 2). The results can be analysed and interpreted in various ways [37]. In this work, empirical equations $\mathrm{y}=\mathrm{a} \ln (\mathrm{x})+\mathrm{b}$ were used, as shown in Table 2. Calculations were carried out in Microsoft Excel. The coefficient of determination $\mathrm{R}^{2}=1-\varphi^{2}$ was adopted as the correlation measure. These equations describe the oxygen concentration only until oxygen saturation is reached; after this, the amount of oxygen does not change, and the graph takes the form of a horizontal line. Table 2 shows the time for which logarithmic behaviour is seen before reaching oxygen saturation.

Table 2. Coefficients of the equation $y=a \ln (x)+b$

\begin{tabular}{|c|c|c|c|c|}
\hline Mixer speed (RPM) & $\mathrm{a}$ & $\mathrm{b}$ & $\mathrm{R}^{2}$ & Time (s) \\
\hline 1000 & 14.41 & 79.44 & 0.961 & 572 \\
\hline 1500 & 24.97 & 128.08 & 0.939 & 470 \\
\hline 2000 & 28.46 & 161.53 & 0.985 & 210 \\
\hline 2500 & 35.14 & 168.9 & 0.922 & 270 \\
\hline 3000 & 39.11 & 202.37 & 0.924 & 280 \\
\hline 3500 & 39.92 & 219.09 & 0.927 & 280 \\
\hline 4000 & 40.88 & 237.75 & 0.963 & 150 \\
\hline
\end{tabular}




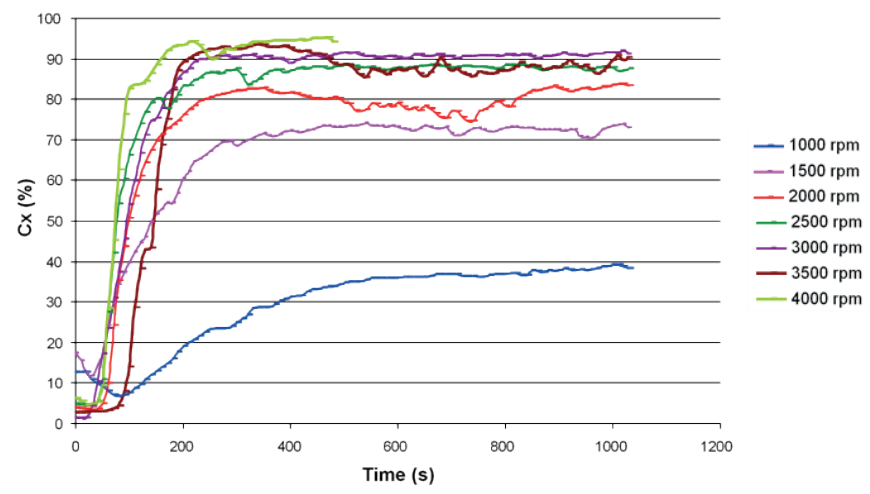

Fig. 3. Oxygen concentration in chamber 2 at different mixer speeds.

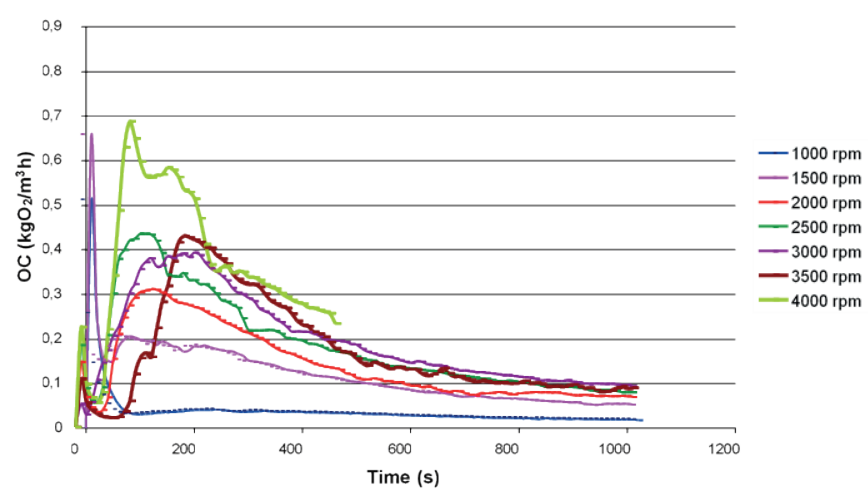

Fig. 4. Oxygenation capacity in chamber 2 at different mixer speeds.

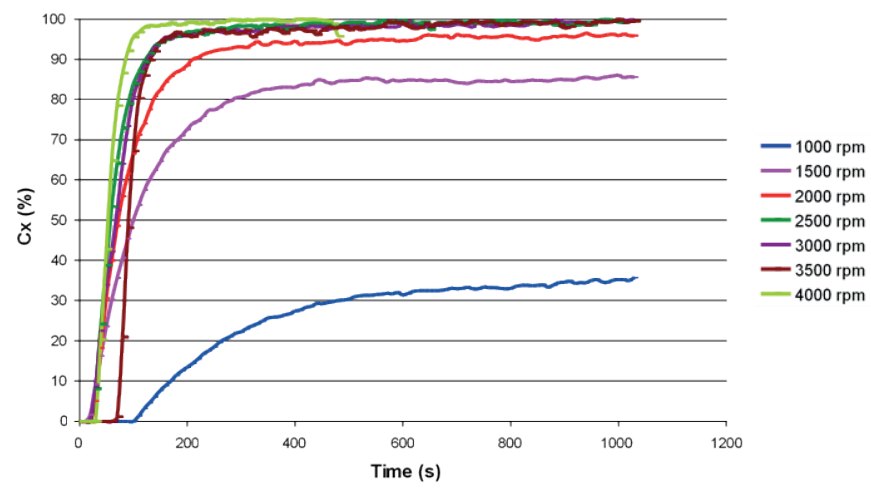

Fig. 5. Oxygen concentration in chamber 1 at different mixer speeds.

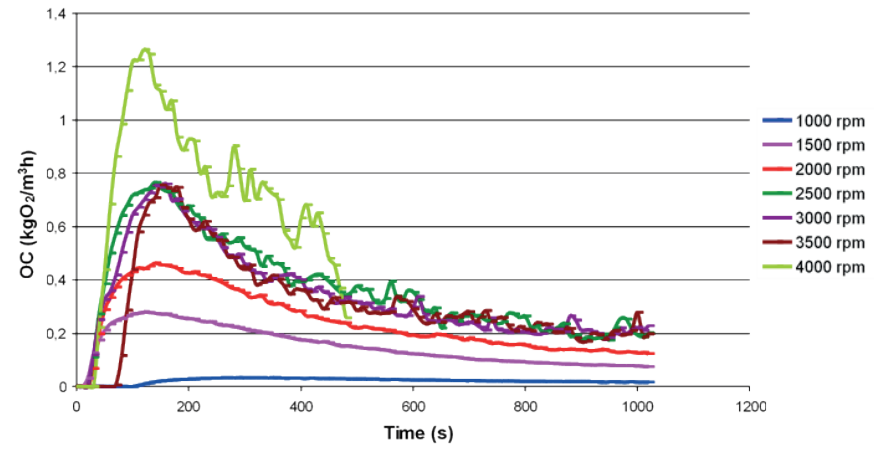

Fig. 6. Oxygenation capacity in chamber 1 at different mixer speeds.

\section{SUMMARY}

The results of the experiment indicate that our selfaspirating tubular mixer is an effective aeration device. The mixer has a simple structure, which does not require an external air supply source, and this reduces the operating costs. Aeration intensity was calculated using the ratio of the observed oxygen concentration to the potential oxygen concentration that can be achieved at a given temperature. The self-designed tubular mixer enabled the relatively rapid achievement of the target oxygen saturation: target saturation values were obtained within approximately $100 \mathrm{~s}$ at mixing speeds of 2500-4000 rpm (Figs. 3 and 5), although aeration was less effective at lower rotational speeds. Oxygen concentration became stabilised over successive stages of aeration, and significant changes in this parameter were not observed during continued mixer operation.

It should also be noted that the self-designed mixer has relatively low power requirements for rotational speeds of $500,1000,1500,2000,2500,3000,3500$ and $4000 \mathrm{rpm}$. This can be largely attributed to the small size of the mixer, and the small tube diameters and short arms. Due to its small size and low energy requirements, the mixer is suitable for use in domestic wastewater treatment systems and in water treatment installations.

In summary, the proposed self-aspirating tubular mixer can achieve a high oxygenation intensity within a relatively short operating time. Its design is very simple, cheap and straightforward. However, questions remain about the possibility of cooperation of such mixers working in the technological line. The effect of the distance between the mixers may affect the oxygenation values obtained, and rotational speeds may be important. In future work, simulations could be carried out using hydraulic software and compared with experimental results.

\section{REFERENCES}

1. Gamo, T. (2011): Dissolved oxygen in the bottom water of the Sea of Japan as a sensitive alarm for global climate change. TrAC Trends in Analytical Chemistry, 30(8), 1308-1319.

2. Topcu, H. D., Brockmann, U. H. (2015): Seasonal oxygen depletion in the North Sea, a review. Marine Pollution Bulletin, 99(1-2), 5-27.

3. Stigebrandt, A., Kalén, O. (2013): Improving oxygen conditions in the deeper parts of Bornholm Sea by pumped injection of winter water. Ambio, 42(5), 587-595.

4. Mostefa, G., Ahmed, K. (2012): Treatment of water supplies by the technique of dynamic aeration. Procedia Engineering, 33, 209-214.

5. Stigebrandt, A., Liljebladh, B., De Brabandere, L., Forth, M., Granmo, Å., Hall, P., ... Norén, F. (2015): An experiment 
with forced oxygenation of the deepwater of the anoxic By Fjord, Western Sweden. Ambio, 44(1), 42-54.

6. Grochowska, J., Gawronska, H. (2004): Restoration effectiveness of a degraded lake using multi-year artificial aeration. Polish Journal of Environmental Studies, 13(6).

7. Wang, J., Liu, X. D., Lu, J. (2012): Urban river pollution control and remediation. Procedia Environmental Sciences, $13,1856-1862$

8. Anielak, A. M. (2015): Wysokoefektywne metody oczyszczania wody.

9. Salgot, M., Folch, M. (2018): Wastewater treatment and water reuse. Current Opinion in Environmental Science Health.

10. Ribeiro, A. R., Nunes, O. C., Pereira, M. F., Silva, A. M. (2015): An overview on the advanced oxidation processes applied for the treatment of water pollutants defined in the recently launched Directive 2013/39/EU. Environment International, 75, 33-51.

11. Matilainen, A., Sillanpää, M. (2010): Removal of natural organic matter from drinking water by advanced oxidation processes. Chemosphere, 80(4), 351-365.

12. Kanakaraju, D., Glass, B. D., Oelgemöller, M. (2018): Advanced oxidation process-mediated removal of pharmaceuticals from water: A review. Journal of Environmental Management, 219, 189-207.

13. Dewil, R., Mantzavinos, D., Poulios, I., Rodrigo, M. A. (2017): New perspectives for advanced oxidation processes. Journal of Environmental Management, 195, 93-99.

14. Oller, I., Malato, S., Sánchez-Pérez, J. (2011): Combination of advanced oxidation processes and biological treatments for wastewater decontamination-A review. Science of the Total Environment, 409(20), 4141-4166.

15. Särkkä, H., Bhatnagar, A., Sillanpää, M. (2015): Recent developments of electro-oxidation in water treatment-A review. Journal of Electroanalytical Chemistry, 754, 46-56.

16. Kumar, A., Nidheesh, P. V., Kumar, M. S. (2018): Composite wastewater treatment by aerated electrocoagulation and modified peroxi-coagulation processes. Chemosphere, 205, 587-593.

17. Roksela, M., Heidrich, Z. (2017): Energochłonność napowietrzania w procesie osadu czynnego. Gaz, Woda i Technika Sanitarna.

18. Asadi, A., Verma, A., Yang, K., Mejabi, B. (2017): Wastewater treatment aeration process optimization: A data mining approach. Journal of Environmental Management, 203, 630-639.

19. Daskiran, C., Riglin, J., Schleicher, W. C., Oztekin, A. (2018): Computational study of aeration for wastewater treatment via ventilated pump-turbine. International Journal of Heat and Fluid Flow, 69, 43-54.

20. Kalenik, M., Wichowski, P., Morawski, D., Chalecki, M. (2017): Kinetics of water oxygenation in pipe aerator. Infrastruktura i Ekologia Terenów Wiejskich.

21. Marsidi, N., Hasan, H. A., Abdullah, S. R. S. (2018): A review of biological aerated filters for iron and manganese ions removal in water treatment. Journal of Water Process Engineering, 23, 1-12.

22. Bao, T., Chen, T., Wille, M. L., Chen, D., Bian, J., Qing, C., ... Frost, R. L. (2016): Advanced wastewater treatment with autoclaved aerated concrete particles in biological aerated filters. Journal of Water Process Engineering, 9, 188-194.

23. Kujawiak, S., Gawrońska, A., Matz, R., Makowska, M. (2017): Efektywność procesu napowietrzania w reaktorach barbotażowych ze złożem ruchomym. CzasopismoTechniczne, 2017 (Volume 3).

24. Boog, J., Nivala, J., Aubron, T., Mothes, S., van Afferden, M., Müller, R. A. (2017): Resilience of carbon and nitrogen removal due to aeration interruption in aerated treatment wetlands. Science of The Total Environment, 621, 960-969.

25. Freeman, A. I., Surridge, B. W., Matthews, M., Stewart, M., Haygarth, P. M. (2018): New approaches to enhance pollutant removal in artificially aerated wastewater treatment systems. Science of the Total Environment, 627, 1182-1194.

26. Shukla, B. K., Goel, A. (2018): Study on oxygen transfer by solid jet aerator with multiple openings. Engineering Science and Technology: An International Journal, 21(2), 255-260.

27. Shukla, B. K., Khan, A., Saikiran, G., Sriram, M. A. (2019) Comparative study on effect of variation in opening shape on oxygenation performance of surface jet aerators used in water and wastewater treatment. Journal of Green Engineering, 9(3), 427-440.

28. Ghotli, R. A., Shafeeyan, M. S., Abbasi, M. R., Raman, A. A. A., Ibrahim, S. (2020): Macromixing study for various designs of impellers in a stirred vessel. Chemical Engineering and Processing - Process Intensification, 148, 107794.

29. Adel, M., Shaalan, M. R., Kamal, R. M., El Monayeri, D. S. (2019): A comparative study of impeller aerators 
configurations. Alexandria Engineering Journal, 58(4), 1431-1438.

30. Du, Y., Chen, F., Zhou, L., Qiu, T., Sun, J. (2020): Effects of different layouts of fine-pore aeration tubes on sewage collection and aeration in rectangular water tanks. Aquacultural Engineering, 102060.

31. Jegatheeswaran, S., Kazemzadeh, A., Ein-Mozaffari, F. (2019): Enhanced aeration efficiency in non-Newtonian fluids using coaxial mixers: High-solidity ratio central impeller with an anchor. Chemical Engineering Journal, 378, 122081.

32. Rzyski, E., Stelmach, J. (2005): Napowietrzanie z użyciem mieszadła ze zwiniętymi śrubowo łopatkami wstęgowymi. Inżynieria i Aparatura Chemiczna, (5s), 58-62.

33. Stelmach, J. (2006): Efektywność mieszadeł turbinowotarczowych z kierownicą. Przemyst Chemiczny, 85(8-9), 1150-1153.

34. Heim, A., Stelmach, J. (2009): Porównanie efektywności wnikania masy dla mieszadeł $\mathrm{z}$ napowietrzaniem bełkotkowym. Rocznik Ochrona Środowiska, 11, 207-219.

35. Rieger, F., Jirout, T., Stelmach, J. (2017): Wpływ modyfikacji mieszadła z łamanymi łopatkami na efektywność mieszania. Przemyst Chemiczny, 96.

36. Suschka J., Zieliński J. (1979): Grajcar E. Urządzenia do natleniania ścieków. Warszawa, Wydawnictwo Arkady.

37. Burgan, H.I., Aksoy, H. (2020): Monthly flow duration curve model for ungauged river basins. Water, 12, 338.

\section{CONTACT WITH THE AUTHORS}

\author{
Andrzej Wróblewski \\ e-mail:andrzej.wroblewski@uwm.edu.pl
}

Aldona Skotnicka-Siepsiak

e-mail: aldona.skotnicka-siepsiak@uwm.edu.pl

University of Warmia and Mazury in Olsztyn, Michała Oczapowskiego 2

10-719 Olsztyn,

Poland 